New Political Economy

\title{
Globalisation and/or Europeanisation? The Case of Flexicurity
}

\section{Dimitris Tsarouhas \& Stella Ladi}

To cite this article: Dimitris Tsarouhas \& Stella Ladi (2013) Globalisation and/or Europeanisation? The Case of Flexicurity, New Political Economy, 18:4, 480-502, DOI: 10.1080/13563467.2012.717612

To link to this article: https://doi.org/10.1080/13563467.2012.717612

曲 Published online: 18 Oct 2012.

Submit your article to this journal

Џll Article views: 687

Citing articles: 5 View citing articles $ک \pi$ 


\title{
Globalisation and/or Europeanisation? The Case of Flexicurity
}

\author{
DIMITRIS TSAROUHAS \& STELLA LADI
}

The relationship between globalisation and Europeanisation is conventionally studied by focusing on the domestic level. In this article we explore this relationship at the international level instead. We examine the way in which the two phenomena in the form of the ILO and the EU relate to one another. Adopting a discursive institutionalist approach and focusing on flexicurity, we investigate whether, how and under what conditions the discourse on flexicurity provides a point of convergence or divergence between globalisation and Europeanisation. Our empirical data reveals attempts by the European Commission to use globalisation as a legitimating device for a market-accommodating programme for labour market reform. The ILO remains more sceptical, both about the overall effects of globalisation and the more concrete uses of flexicurity. Meanwhile, the concept of flexicurity is subject to change and rearticulation in line with the evolving policy agenda endorsed by the Commission and/or the member states. The relationship between Europe and globalisation is thus far from neutral. 'Europe' is active in shaping globalisation; translated into the work undertaken here, Europeanisation could be conceived as a facet of globalisation rather than as a bulwark to it, or merely as a process running parallel to it.

Keywords: Europeanisation, globalisation, discourse, flexicurity, EU, ILO

\section{Introduction}

Globalisation and Europeanisation are terms with wide-ranging appeal that has made them popular among politicians, commentators and scientists alike. Though their trajectory of growth and subsequent popularisation is slightly different, their use often tends to be confusing insofar as the two phenomena tend to be conflated, mistaken for each other or used interchangeably to denote a wide range of socio-economic changes (Rosamond 2003). To disentangle globalisation from Europeanisation and in contrast to most of the literature (e.g. Verdier and Breen 2001; Levi-Faur 2004), we focus on the impact of globalisation and

Dimitris Tsarouhas, Bilkent University, Ankara, Turkey. Email: dimitris@bilkent.edu.tr Stella Ladi, School of Business and Management, Queen Mary, University of London, Mile End Road, London E1 4NS, UK 
Europeanisation at the international level rather than the domestic one. In particular, the comparison here concerns the discourses that the European Union (EU) and the International Labour Organisation (ILO) use to promote or to delimit the spread of flexicurity. The EU and the ILO are understood as institutional manifestations of Europeanisation and of globalisation respectively.

Before proceeding it is important to clarify what the article is not about. First, we deal with the utilisation and relationship between the two phenomena only. We thus do not preoccupy ourselves with the series of important questions that arise once we consider the possibility that these terms are subject to doubt considering their material effects. This holds true both for globalisation, where the debate between sceptics and 'hyperglobalists' has been going on for some time, and for Europeanisation. Regarding the latter and considering that we are interested in the use of the term to understand the thought processes and discursive practices that key institutions engage in so as to shape their policy agenda, the extent to which Europeanisation is 'real' need not preoccupy us here. Suffice to say that the literature on the subject has grown exponentially over the last two decades and now encompasses almost the full range of policies related to European integration, whether in a 'bottom-up', 'top-down', 'multilevel', 'regulatory' or other manner.

We should also clarify why we look at the issue of discourse through the prism of flexicurity. The onset of globalisation defined as an accelerated pace of economic liberalisation leading to the gradual dislocation of capital from its home base' has also affected labour markets. By looking at a concrete manifestation of labour market policies, namely flexicurity, we seek to understand the wider processes of policy construction at global and European levels, demonstrate the linkages between the two and assess their origins and policy impact. Moreover, flexicurity is a helpful case because, as the article demonstrates, it is a concept developed at EU level and thus linked to Europeanisation. Therefore, even if it is difficult to establish direct causality, there are more linkages between Europeanisation and the spread of flexicurity compared, say, to 'Americanisation'.

Our empirical data reveals consistent attempts by the European Commission to use globalisation as a legitimating device for a market-accommodating programme of labour market reform. The ILO remains more sceptical, both about the overall positive effects of globalisation and the more concrete uses of flexicurity in changing the labour market. Nevertheless, the ILO approach on flexicurity is heavily influenced by EU activism on the field, and EU leadership in communicating flexicurity beyond Europe is accepted by the ILO. Meanwhile, the concept of flexicurity is subject to change in line with the evolving policy agenda endorsed by the Commission and/or the member states. These findings allow us to argue that the relationship between Europe and globalisation is far from neutral or passive. To the contrary, 'Europe' as an institutional and political actor is active in shaping globalisation (Jacoby and Meunier 2010). Translated into the work undertaken here, Europeanisation could be conceived as a facet of globalisation rather than as a bulwark to it, or merely as a process running parallel to it.

The theoretical framework of discursive institutionalism (DI) is helpful in our analysis (Schmidt 2008). Comparing the way the discourse on flexicurity is co-ordinated and communicated by the EU and the ILO allows us to observe 
instances of convergence and divergence between the two organisations and as a result demystify the relationship between globalisation and Europeanisation. An asset of this article is that the comparison of discourses takes place at a multilevel environment, which is inherently complex, and thus reveals the strengths as well as weaknesses of the coordinative-communicative discourse dichotomy that discursive institutionalism employs.

The article begins with a discussion of the literature linking globalisation and Europeanisation to introduce our research design and focus. We go on to explain how discourse is operationalised as well as why DI is useful for our purposes. We then apply this framework to the cases of the EU and ILO, respectively. We investigate whether, how and under what conditions the discourse of flexicurity provides a point of convergence or divergence between the two organisations. The conclusion summarises the main results and links our empirical findings with the article's theoretical concerns.

\section{Comparing the phenomena of globalisation and Europeanisation}

The analysis of the relationship between Europeanisation and globalisation is not an easy task. Both phenomena are multi-dimensional and their definitions often abstract. Rosamond (2008) has shown that the two terms are deployed and developed by policy communities in line with a set of material as well as normative policy positions. This article attempts to limit this vast spectrum by investigating their relationship at the international level. In particular, it focuses on the relationship between globalisation and Europeanisation and how they translate into policies in the field of labour markets. The main question is whether we can distinguish between the two and thus between the policies they promote.

Both terms are used in the literature to describe how interdependence and integration at the international level affect the institutions, functions, discourses and policies of states. In this article globalisation is understood as a phenomenon that does not cause the decrease of state sovereignty but does cause changes in its functions and structures (Cerny 1996: 617-37). As far as Europeanisation is concerned, Radaelli's (2003: 3) well-known definition is adopted, according to which the term Europeanisation describes 'processes of (a) construction, (b) diffusion, and (c) institutionalisation of formal and informal rules, procedures, policy paradigms, styles, "ways of doing things", and shared beliefs and norms which are first defined and consolidated in the making of EU public policy and politics and then incorporated in the logic of domestic discourse, identities, political structures, and public policies'. In this article, it is argued that in order to explore the relationship between the two phenomena we need to understand how they affect each other and not only how they affect the domestic level.

The debate on the relationship between globalisation and Europeanisation has been increasing in the last few years. There is agreement that globalisation and Europeanisation are closely related, but there are differences regarding the degree of integration of the two phenomena (Ladi 2006). One approach claims that Europeanisation is a 'filter' for globalisation (Wallace 2000) or even an 'antidote' to globalisation (Graziano 2003). Europeanisation as a 'filter' signifies the capacity of the EU for deep co-operation on issues of political economy as well 
as on other issues, which allows for a selective reaction to the pressures of globalisation (Wallace 2000). Europeanisation as an 'antidote' refers to the capacity of Europeanisation to act not only as a filter but also to promote policies and institutions that affect the same processes of globalisation towards more socially just policy developments. Graziano (2003) wonders whether in the future we will be able to talk about the 'Europeanisation of globalisation'. What is characteristic of this approach is that the EU is seen as mediating between the state and globalisation, which means that it is understood not as part of globalisation but as external to it.

A different approach conceives globalisation as the main force that drives international change and sees Europeanisation as following the trends set out by globalisation. For example, Levi-Faur (2004) in a study of the liberalisation of telecoms and electricity regimes of EU and non-EU member states comes to the conclusion that Europeanisation matters in a less obvious and less critical way than globalisation. This finding is confirmed by the study of the Spanish and Portuguese telecommunications and electricity sectors (Jordana et al. 2006). Della Sala (2004) in his study of public sector reforms in Italy comes to the same conclusion. The argument is that Europeanisation plays an indirect role in the process of change and that there are global pressures that are more prominent. Verdier and Breen (2001) apply a quantitative research design in four different dimensions and observe that in policy areas such as the labour market and the capital market it is globalisation that mainly accounts for change while in electoral competition and centre-local government relations the EU plays an important role.

A reverse argument is put forward by Scharpf (2002). In his study of the European Social Model (ESM) he shows that, if anything, the European Union has limited the options of member-states to "supply-side strategies involving lower tax burdens, further deregulation and flexibilization of employment conditions, increasing wage differentiation and welfare cutbacks' (Scharpf 2002: 649). He further argues that World Trade Organization (WTO) rules are less constraining, highlighting that it is not globalisation that limits states' choices on social policy. This is an interesting conclusion, which is in accordance with our own finding about the ILO being less sanguine than the EU on the benefits of flexicurity. Scharpf's argument could signify the 'Europeanisation of globalisation', not as Graziano imagines it but rather as an additional push towards liberalisation.

Scharpf's line of argument is taken further by reversing the logic that most EU scholars have been following and actually explore the way the EU affects globalisation. Jacoby and Meunier (2010) in their review remind us that the EU has been essential in shaping the global environment. They argue that the main mechanisms used by the EU include writing the rules of globalisation (for instance on global trade), transferring European regulations and standards to the global level and serving as a model for the international community. Their analysis is based on examples that concern the economic aspects of globalisation and Europeanisation but their claims could be generalised. This article, in agreement with Jacoby and Meunier, claims that the EU is active in shaping globalisation by transferring flexicurity at the global level and by serving as a model for the international community in the field of labour market policies. This then means that Europeanisation 
can be described as one of the key facets of globalisation rather than a mere follower of policy options shaped and led by the alleged imperatives of globalisation.

A variety of research designs has been applied in the studies aiming to relate globalisation with Europeanisation. What most of them have in common is that they attempt to distinguish the effects of globalisation from those of Europeanisation at the domestic level. One approach is to look at country specific case studies (Graziano 2003; Della Sala 2004). The advantage of this approach is the resulting in-depth empirical analysis shedding light on the different effects of the two phenomena. A second strategy is to select specific sectors or dimensions of domestic politics where change is underway and offer a comparative quantitative analysis (Verdier and Breen 2001; Levi-Faur 2004). The strength of that approach is that it is possible to discover different effects of Europeanisation and globalisation on different sectors depending, for example, on how liberalised or deregulated they are. Although there are advantages in these approaches there are aspects of the globalisation-Europeanisation relationship that remain hidden through this type of research. The design proposed here differs in the unit of analysis that is compared, namely neither countries nor policy sectors. Instead, we compare international organisations and in particular the discourses that the EU and the ILO use to promote or to delimit the spread of flexicurity.

Hay and Rosamond (2002) discuss the way discourses matter in policy making in different European countries. For them 'it is the ideas that actors hold about the context in which they find themselves rather than the context itself which informs the way in which actors behave' (Hay and Rosamond 2002: 148). The authors show that some European countries blame the EU and not globalisation for similar (and painful) social and economic reforms that other member states have attributed to globalisation. This conclusion underscores the importance of discourse regarding globalisation and Europeanisation. We suggest that in order to shed light on the relationship between globalisation and Europeanisation the deployment of the discourse of flexicurity at the international (ILO) and European (EU) level has to be further explored. The theoretical and methodological tools of discursive institutionalism are of great assistance to this exercise.

Discursive institutionalism has been outlined by Schmidt (2008) as a fourth type of institutionalism distinct from the rational choice, historical and sociological versions. It reflects the turn to ideas and discourse in political science (Hall 1993; Blyth 2002). Institutions are understood as the context within which agents think, speak and act and at the same time as the result of agents' thoughts, words and actions. Discourse as developed in DI describes the substantive content of ideas but also the interactive process by which ideas are spread.

Discourse is not just about ideas or 'text' but also, as in Hay and Rosamond (2002), about the context in which the ideas are developed and promoted. Hay and Smith (2010), point to the strategic use of discourse by policy-makers aiming to insulate otherwise problematic policy positions from criticism. In so doing they add a necessary layer of complexity to a discourse based approach by alerting us to the need to keep the distinction between private and public discourse in mind. Moreover, Hay and Rosamond (2002) stress the conscious depiction of both globalisation and European integration as external imperatives driving a reform course with which policy-makers may not wish to be associated, not least 
because of the expected electoral backlash that such a course (fiscal austerity and welfare retrenchment) is associated with. Schmidt and Radaelli (2004: 193) clarify that the study of discourse should coexist with the awareness that interests also matter, as well as material conditions and 'hard' economic variables. Empirically, what is interesting is to shed light on cases where discourse proves central in the development of events and to pick the exact time and the agents that are responsible for its development. This is what we aim to do in our case study of flexicurity.

\section{Operationalising discourse and the concept of flexicurity}

To detect how the discourse on flexicurity is utilised we distinguish between the coordinative and communicative aspects of the EU and ILO discourses so as to locate points of convergence and divergence between forces of Europeanisation and globalisation. We focus on the Commission due to its extensive role in shaping the relevant discourse, although the cooperation between the European Council and the Commission means that it is an EU discourse that emerges after all. Such an approach has thus far been largely overlooked in the literature and thus has not been fully utilised. The application of the coordinative and communicative discourse classification at a multi-level environment demonstrates the complexity of discourse. Discourse is a dynamic phenomenon that, depending on the exact time of the examination, can present more, or less, coordinative and/or communicative characteristics.

Coordinative discourse takes place within the institution concerned and refers to the 'creation, elaboration, and justification of policy and programmatic ideas' by policy actors and the way they exchange views and persuade each other. It is concerned with the formation of a common language on the part of policymakers in their attempt to construct a coherent policy programme (Schmidt 2002: 171) and focuses on the promoters of ideas. This is not to say that all members of an institution or group are equal in the formation of coordinative discourse; policy entrepreneurs maintain an advantage as they are tasked with generating and propagating ideas to others (Peters 2011). Our discussion below on asymmetrical power relationships in formulating discourse confirms that view.

The construction of coordinative discourse is even more complex at multi-level environments such as the EU and the ILO. Communicative discourse is concerned with ideas themselves and the attempt to convince about their appropriateness. It refers to 'the presentation, deliberation, and legitimation of political ideas to the general public' (Schmidt 2008: 310). Communicative discourse, similarly to the coordinative variant, can be said to be more complex at multi-level environments where many agents act and rarely speak with exactly the same voice, even after decisions are made and international agreements are signed. From a methodological point of view, the depiction and articulation of communicative discourse is an easier task compared to the coordinative variant, as publicly available data offers a fairly reliable avenue of evaluating it. Coordinative discourse in contrast mainly emerges through personal interviews and direct communication with policy actors.

Flexicurity is a concept whose origins lie at national level. It was first implemented by the Danish government in 1993 as well as the Dutch 
administration in the 1990s through its Flexibility and Security Act (Viebrok and Clasen 2009: 7). The approach soon reaped benefits in that it combined employment growth with a large cut in the then burgeoning Danish deficit. A similar success in the Netherlands led to attempts by the European Commission to export flexicurity elsewhere in the Union. In so doing the Commission was supported by a series of newly elected governments in the EU, not least in the UK, favouring a Third Way-type approach to labour market policy (Giddens 1998). That approach promised to reconcile the demands of capital and labour by offering more flexibility to business in return for employee protection. The origins of the concept is thus a highly important issue and can reveal different layers of coordinative and communicative discourse between the member states before it was adopted by the EU, which is the moment at which the present analysis begins (see Antoniades 2008). Space limitations do not allow us to analyse this issue here further.

How is the term to be understood? There is not one definition that includes the entire spectrum of policies potentially covered under the term, and its meaning is contested. In fact, one could speak of competing definitions of the term. Employers and some governments saw in it a way of cutting down on welfare and enhancing profitability through a 'less rigid' (that is, less worker-friendly) 'hire-and-fire' legislative framework. Meanwhile labour representatives sought to interpret it as a method of enhancing employee security through investment in education, the upgrading of skills and adequate welfare support in times of unemployment.

It has been argued that since the early 2000s flexicurity has meant a turn towards workfare-like employment programmes stressing 'employment' policy instead of the more comprehensive 'labour market policy' that the Danish authorities had adopted in the 1990s (Jørgensen 2011). Flexicurity is an evolving concept subject to different agendas at both national and EU level. As the purpose of this article is not to analyse the concept itself we limit ourselves to defining it as a European way of dealing with globalisation (Antoniades 2008: 333) that seeks to bridge the 'Anglo-Saxon' inclination to instil more 'flexibility' in the labour market with the 'Continental' approach that favours balancing flexibility with employee protection. This underlines the European origins of the concept and facilitates its use to depict processes of Europeanisation.

Finally, it is crucial to stress that for the purposes of our article the EU is linked to Europeanisation as it constitutes its main source, while the ILO is a case study of an international organisation and a global standards-setter in labour market policy and employment issues. This has been especially true since the 1990s, when the ILO started the promotion of its policy agenda centred on the need to adopt and implement Core Labour Standards (CLS). Furthermore, the ILO has with time gained a stronger international presence and raised its visibility, not least through its enhanced cooperation with the IMF and the World Bank to promote a 'labour friendly' development agenda. The fact that the 2009 G-20 meeting in Pittsburgh invited the ILO to submit a report on weathering the global economic crisis is indicative of its recently enhanced profile (ILO 2009b). 
Sources and methods

To analyse the extent and function of coordination and communication in the EU and ILO discourse we rely on process-tracing. Primary documentation stemming from the European Council, the Council Secretariat and the European Commission is used to understand the usage and the meaning ascribed to flexicurity by the Union. These take the form of policy reports, opinions, consultation documents and communications. The same is done for the ILO, as we trace the official policy pronouncements of the organisation in its annual Conference, in Regional Meetings, and International Labour Office data, reports and publications. To obtain a full picture of both organisations' discursive practices and to reveal their discursive points of convergence or divergence, we also conducted firsthand interviews with senior officials from the European Commission and the ILO and followed these up with personal communications when the need arose to clarify a few issues.

\section{The EU's discourse on flexicurity}

Distinguishing between the EU's coordinative and communicative discourse on flexicurity is interesting because it reveals a much more diverse set of actors participating in the coordination of the discourse than in its communication. The actors that interact for the coordination of the flexicurity discourse include the European Commission, the European Council, member state governments, the European Experts' Group and the social partners, that is, the European Trade Union Confederation (ETUC), the European Employers' and Industrialists' associations (CEEP and BusinessEurope), the European Chamber of Commerce and Industry (Eurochambres) and the organisation for SMEs and craft organisations (UEAPME). Moreover, their power relationship is highly asymmetrical, as a business view on flexicurity is expressed by multiple actors whereas ETUC is the sole voice representing labour on the flexicurity debate. When it comes to communicating discourse, this task is limited to the Commission and the European Council.

Before discussing the coordinative and communicative discourse of the EU further, it is important to mention that one important dimension of the relationship between globalisation and Europeanisation concerns the role of political leadership in shaping a particular discourse about globalisation and the role of the EU in it. Concretely, the European Commission's discourse on the subject has been transformed over time, and a comparison between the Delors era and subsequent rhetorical action by the Commission highlights this crucial point. ${ }^{1}$

The Delors era saw an attempt to support policies that highlighted the salience of the ESM as a bulwark to pure market liberalism (Jepsen and Pasqual 2005: 234). Under the leadership of Delors, economic integration and social policy went hand in hand, and that was due to the Commission President's desire to achieve upward harmonisation of socio-economic standards in the context of a 'European model of society' (Hay et al. 1999: 7). This was a political strategy, expressed in initiatives regarding social partnership and social policy legislation, which ran contrary to the depiction of globalisation as limiting Europe's room to manoeuvre. 
Yet the post-Delors era is marked by a different stance by the Commission. Over time, the latter came to embrace a particular mode of the ESM that saw it as a European solution to a constructed policy problem, namely that of lack of competitiveness. The difference with the Delors era could not be clearer. Social policy, and the notion of flexicurity among others, became part of an attempt to equip the individual with capacities allowing her to survive the pressures of a competitive, globalised economy instead of conceiving it as a solid pillar of the European model of society. This conceptualisation was part of an attempt to boost EU legitimacy and construct a European identity based on sharing not only problems, but also increasingly notions and concepts (Jacobsson 2004), one of which is flexicurity.

\section{Coordinative discourse}

The European Commission started referring to the concept in the 2000 Lisbon Strategy and the perceived successes of flexicurity at national level. In 2001 the Employment Guidelines included an explicit reference to the need to achieve a better balance between private and working life by combining flexibility with security (Wilthagen and Tros 2004: 168). In 2003 and 2005 the Guidelines were revised to reflect a balance between flexibility and employee security in labour market reform. After the 2006 Villach meeting on social and employment policy the concept of flexicurity was officially adopted by the Commission and since 2007 flexicurity and associated policy concepts are part of the European Employment Strategy (EES) (Tangian 2007: 553) and were included in the 2008-2010 EES Guidelines. The Villach Summit was very important: though only an informal meeting of the Employment and Social Affairs Council, it came up with a working definition of flexicurity that centred on four components: 'Flexible and reliable contractual arrangements, effective active labour market policies, comprehensive lifelong learning strategies and modern social security systems' (Mailand 2010: 244; Council Presidency 2006. In this section it is shown that globalisation has played a primary role in the EU's coordinative discourse on flexicurity.

The precise definition of flexicurity and thus its coordinative discourse remained contested and the European Council requested that the Commission come up with common flexicurity principles. These could then be integrated in the Lisbon Strategy and be part of the National Reform Programmes. In 2006 a Commission Green Paper called for 'open dialogue' on how to understand flexicurity, a process that would involve 'member state governments, social partners and other relevant stakeholders'. In a 2007 Communication the Commission outlined eight principles. Flexicurity meant 'flexible and reliable contractual arrangements, modern social security systems, effective labour market policies, a balance between rights and responsibilities as well as internal and external flexicurity' to help employees make beneficial labour market transitions (European Commission 2007b: 4).

The Commission sought to coordinate its discourse on flexicurity with the relevant social partners, primarily ETUC, CEEP and BusinessEurope. These 'stakeholders' would have the opportunity to address the Commission directly as they 
are official EU social partners since the Maastricht Treaty. Their different responses reveal their divergent views on the concept. While the ETUC worried that flexicurity was turning into an issue associated with 'flexible' (easy) layoffs (ETUC 2007), BusinessEurope welcomed the Commission's initiative since flexicurity could help member states tackle 'structural labour market problems'. A positive approach was also echoed by Eurochambres and UEAPME (Euractiv 2007).

Thus, part of the flexicurity approach endorsed by the Commission is the need to maintain financially sound budgetary policies since 'flexicurity policies have budgetary costs', pay particular attention to SME needs when considering the financial implications of a flexicurity programme and use social protection policies to facilitate workers' mobility (European Commission 2007b: 9). While the cornerstone of flexicurity's interpretation is geared towards enhancing EU competitiveness primarily by facilitating enterprise restructuring, the approach is described as a 'win-win' strategy consistent with the ESM. This aspect of the EU discourse results from the member states' desire to see their national priorities reflected in the concept so as to adjust it to their own political and economic circumstances (Antoniades 2008).

The Commission's discourse is promoting a particular labour market pathway that goes through the implementation of a particular type of flexicurity. This discourse is essentially twofold. First, it asserts that flexicurity emerges in parallel to globalisation's inevitable arrival and second, is intimately connected to technological change and the revolution the latter has caused in the production, consumption and lifestyle habits of employers, employees and citizens alike. According to the Commission flexicurity is the logical point of arrival following technological progress, which is inevitably bound to affect peoples' working lives at different levels (Interviews 2 and 3). The 2007 European Experts' Group identified four factors that led to structural economic change. Two of them are the 'rapid development of new technologies' and the 'fast pace of international economic integration' (European Expert Group 2007: 8).

The second paragraph of a 2007 Commission Communication reads as follows: 'Overall, globalisation is beneficial for growth and employment, but the change it brings requires rapid responses from enterprises and workers' (European Commission 2007a: 3). There is little doubt therefore that globalisation ought to be welcomed as a process that enhances Europe's welfare. The next step should be to make fuller use of its allegedly beneficial effects by preparing both the workforce and enterprises for globalisation's set of inescapable 'demands'.

Writing on behalf of the Bureau of European Policy Advisers (BEPA), Liddle and Lerais argue in a Consultation Paper to the European Commission entitled 'Europe's Social Reality' that globalisation does little else than accelerate already existent trends within the ESM, trends related to deindustrialisation, an ageing society and technological change. Hence, 'it is a myth to believe in a timeless European social model which has now been subject to a "globalisation shock" (Liddle and Lerais 2007: 7). ${ }^{2}$

The relationship between globalisation and the ESM is thus framed in such a way that makes: (1) the process of change endogenous to ESM and not the result of a need to respond to globalisation, (2) the necessity of change inescapable 
and (3) the direction of change towards more flexible labour market arrangements inevitable, considering that globalisation comes together with pressure for enhanced levels of competitiveness.

As the Commission states in its 2007 Communication on flexicurity:

To confront the multiple challenges of a fast-evolving global economy and an ageing workforce, the European Union needs to find new and better ways of making its labour markets more flexible while at the same time providing new and better forms of employment security. (European Commission 2007a: 1)

Clearly then, flexicurity may (or indeed ought to) take different forms in different member states. But the challenge to Europe's economic standing and social cohesion is said to be common to all, and flexicurity serves as a rallying cry to bring diverse systems under a common roof operating on the basis of a common flexicurity manual. In this vein the Commission launched the 'Mission for Flexicurity' in 2008, an expert group comprising diverse stakeholders (Commission, European Council, social partners) to 'promote the implementation of flexicurity in different national contexts by raising the profile of the flexicurity approach' (emphasis added, European Council 2008: 4).

More evidence pointing to the Commission's activism has emerged. Officials from the Directorate General for Employment and Social Affairs have pushed for flexicurity in the formative stages in 2006 to strengthen the European Employment Strategy (EES) and reconcile the different views on flexicurity that existed among European Council members (Mailand 2010: 244). In 2007 it was again Commission officials who arranged a last minute compromise between the social partners on flexicurity ahead of the European Council meeting of that year, aware of the persisting differences between member states (Mailand 2010: 248). Such activism has allowed flexicurity to remain high on the agenda and be perceived, albeit with increasing scepticism on the part of the unions, as a satisfactory response by the EU to the 'challenge of globalisation' (see also Antoniades 2008).

This is corroborated by evidence stemming from both the Commission and Council (Secretariat and the Employment Committee [EMCO]). The Council Secretariat, in flexicurity-related documents sent to the Employment Social Affairs, Health and Consumer Affairs Committee (EPSCO) in 2007 and 2008 uses a necessarily guarded language on flexicurity. It repeats the mantra of inevitable globalisation and technological change, sees those as necessitating 'far-reaching economic restructuring' and identifies flexicurity as a solution because it allegedly allows both employees and employers to 'take a wider view' on the issue of restructuring (European Council 2008: 4).

The EU's coordinative discourse is to a large extent driven by the Commission on whom the European Council relies to coordinate national positions and engage in dialogue with stakeholders. Both the Commission and the European Council use a discourse that links flexicurity to globalisation's alleged real policy impact and its inescapable constraints and challenges. This, in turn, is a reflection of policy choices made by member states at the domestic level 
and which they wish to see reflected at EU level and beyond (Interviews 3 and 4). In that context, then, it is convenient for member states to argue that the 'necessities' of globalisation call for the adoption of flexicurity. In other words, a particular type of interpretation is ascribed to globalisation, which then combines with domestic political imperatives to push flexicurity on the EU agenda. Finally, this leads to an EU coordinative discourse that continuously stresses the influence of globalisation on its policy choices.

\section{Communicative discourse}

The Commission is the EU's protagonist in communicating a particular type of discourse on flexicurity. This is both because of its institutional role regarding coordination, and its desire to enhance its own role within the EU by highlighting the significance of flexicurity and policies, such as the EES, that flow from it. It is important that in this type of discourse globalisation is used less as an empirical reality and more as a conceptual framework that necessitates action in establishing a 'European labour market'. The Council of the European Union stresses the need to:

Promote the awareness of citizens of flexicurity policies and their importance for the reform of European economic and social models. (emphasis added, Council of the European Union 2007: 3)

The use of plural on Europe's diverse socio-economic systems is a confirmation of an empirical reality but also a potent reminder of divisions between European Council members regarding flexicurity. It is for that reason that the Expert Group chaired by Ton Whilthagen identified four 'pathways to flexicurity'. These reflect some of the common challenges faced by member-states, but had to be drafted in a general manner so as not to identify particular member-states and not exclude others. The pathways entail 'tackling contractual segmentation', flexicurity within the firm, tacking opportunities and skills gaps among the workforce and improving labour market chances for benefit recipients and the informally employed (European Expert Group 2007).

In a 2006 Communication the Commission argues for the need to see flexicurity in a pan-European context:

It is important to put the issue of flexicurity in the broader context of the European employment strategy and at the same time not to make the flexicurity discussion into a debate about any of the individual components alone. (European Commission 2006: 1)

This would then allow the Commission to retain a commanding role in the process. In this 2006 document the Commission makes clear that the aim of strengthening the EES through flexicurity ought not to be hampered by individual preferences for one or other flexicurity element. Instead, it is the adoption of flexicurity by more and more member states that becomes the goal, leaving the actual content of labour market policy resulting from this adoption a bit vague. 
In its Communication entitled Towards Common Principles of Flexicurity the Commission emphasised that the Lisbon targets need to be fulfilled by member states 'and the Union' so as to secure that 'Europe' can adjust to the 'shocks imposed on its economy' (European Commission 2007b: 3). The common principles were put in place so that member states would learn from each other. Moreover, mutual learning and benchmarking should be used to successfully implement the Lisbon Strategy (European Commission 2007b: 10).

By 2010 and whilst assessing the Lisbon project, the Commission declared that member states had moved forward with flexicurity in terms of policy learning and within the context of the Open Method of Coordination (OMC), the preferred way of Europeanising labour market policy at EU level (European Commission 2010: 7). The document argued that flexicurity had been a success and represented the ability of 'Lisbon to stimulate and frame policy debates and generate mutually acceptable solutions' (European Commission 2010: 3). The discourse on flexicurity was thus utilised by the Commission to push forward its agenda on the Europeanisation of labour market policy.

In 2011 the Commission adopted its 'Europe2020 Agenda for new skills and jobs' aiming inter alia at an employment rate of 75 per cent by the year 2020 (European Commission 2011). Stressing that flexicurity had helped many member states weather the economic crisis yet vulnerable groups had been hit hard by it, the document underlined the need to strengthen flexicurity in the post crisis period and rebalance its four components to adjust to the new environment (European Commission 2011: 7-8).

Such a discourse allows the EU and in particular the Commission to portray flexicurity not only as congruent with its vision of Europe's political economy but also as a paradigm that balances employee and employers' interests. However, as Keune and Jepsen (2007) point out, there is little intrinsically new in this debate. Member states have long been using elements of flexicurity in their domestic systems. Their record in combining flexibility with security is mixed, depending on a whole series of institutional factors most of which have little to do with the alleged 'imperatives of globalisation'. It is therefore plausible to argue that the Commission has sought to utilise this debate to disseminate its preferred knowledge on how to deal with contemporary 'economic realities', and at the same time strengthen its institutional position within the Union.

\section{The ILO and its discourse on flexicurity}

Analysing the ILO discourse an even more interesting trend is revealed. Similarly to the EU, discourse coordination involves more actors than its communication. In support to the key argument advanced in this article, we find that the European Commission plays a central role both in the coordinative and the communicative discourse of the ILO.

In discourse coordination key actors are the Secretary General, the International Labour Office (the organisation's permanent secretariat), the Governing Body and the European Commission while in its communication it is the International Labour Office and the European Commission. Due to the nature of the ILO (discussed below) power relationships here are fairly equitable regarding the 
discourse on flexicurity, as workers and employers' groups retain an equally powerful say in the Governing Body. Moreover, the ILO Secretariat can be seen as equivalent to the European Experts' Group, offering specialised advice based on technical reports and policy documentation backed by evidence.

\section{Coordinative discourse}

The ILO was formed in 1919 and was based on an institutional structure consisting of state representatives, 'workers' (trade unions) and 'employers' (employers' organisations). Managing to survive the demise of the League of Nations and flourishing in the post-war years through its 1944 Philadelphia Declaration, the ILO was the first specialised UN agency (Hughes and Haworth 2011: 14). In operationalising the organisation's coordinative discourse and taking into account its role in promoting a global labour market agenda we focus on coordination between the ILO and the EU. Coordinative discourse of the type that the EU engages in is not taking place at the ILO level due to the organisation's decision-making structure. ${ }^{3}$

The latter centres on the annual International Labour Conference, where Conventions and Recommendations are issued and labour standards are adopted. Every state sends a delegation comprising state officials, workers and employers. While state representatives can vote individually, workers and employers are appointed by their government. Majority voting is the rule, and a two-thirds majority is required for the adoption of conventions and recommendations. The Conference agenda is set by the powerful Governing Body, consisting of 28 government members, 14 worker and 14 employer members. The Governing Body, in which the most powerful industrialised states have 10 guaranteed seats (the remaining 18 rotate every three years), elects the Secretary-General. Finally, the International Labour Office supervises the organisation's technical assistance programmes and issues a wealth of reports, studies and data that underpin the work of the Governing Body.

In essence, decisions at the ILO are reached by consensus and extensive informal consultation prior to final decision making. Moreover and despite the fact that on occasion employers vote differently than workers and state representatives, workers, employees and state officials follow a process of continuous internal coordination (Boockman 2003). This important difference with the EU decision-making structure makes the degree and extent of coordination between the ILO and EU member states an important factor in our analysis.

Evidence suggests that the Commission leads the attempt to put flexicurity principles into practice and works closely with the ILO to do so. Commonly agreed policies are important. The two organisations established a formal dialogue in 2001 through an Exchange of Letters and proceeded with a Memorandum of Understanding establishing a 'strategic partnership' in the field of development. The Memorandum entailed common EU-ILO action on the social dialogue, employment and labour standards, all of which are linked to flexicurity (European Commission 2004). That agreement reflected the EU decision to change its earlier approach in promoting core labour standards. Rather than relying on 'social clauses' when concluding trade agreements with third states, it now sought to 
promote social standards through 'dialogue, stimulation and negation within the ILO' (Eichhorst et al. 2010: 19).

A 2008 ILO document claims that flexicurity is an 'indispensable part of the European Social Model' and makes frequent references to EU activism on flexicurity (ILO 2008: 10). The EU influences ILO work in various ways. The EU delegation in the annual ILO Conference is a key actor: 'when the EU takes the floor, delegates stay in the room to listen' (Interview 1). It is important to note that this is not necessarily a reflection of the EU leading by example. Kissack (2009) has shown that while all EU states have ratified the ILO's Core Labour Standards so have another 101 states around the world. The EU's normative ability to shape the ILO debate is not necessarily accompanied by its showing of leadership in a more practical way.

The EU has been able to coordinate its stance on ILO matters and thus exert more influence on the organisation's policy orientation (Saenen and Orbie 2011). The Annual High Level Meetings allow the EU to influence ILO perceptions (Interview 5) but coordination on the part of the $\mathrm{EU}$ is also institutionalised. Before and during every International Labour Conference (ILC) the member states, the Commission and the Presidency meet in Geneva and formulate their position based on the complexity and sensitivity of the topic on the agenda (Saenen and Orbie 2011: 5).

The Commission is a nonvoting observer within the ILO structure and the EU does not ratify ILO Conventions. Yet the Commission is a discursive coordinator in setting the space within which 'acceptable' logics can be formulated in support of a policy position (Nedergaard 2008). Furthermore, the Commission promotes its policy agenda and sends its delegation to the ILO through the European Regional Group, since the ILO allows for the establishment of regional groups (Johnson 2003). Moreover, the Commission signed a Strategic Partnership with the ILO seeking inter alia to influence labour market and employment conditions in developing countries. This would be achieved by influencing the outcome of ILO Conventions and pressurising non-European states to ratify them. Some success has been recorded in that front, as the EU required the ratification of ILO core Conventions from Venezuela, Mongolia and El Salvador (Eichhorst et al. 2010: 40). It is also noteworthy that the EU actively supports the ILO's Decent Work Country Programme by offering financial assistance.

The Council Presidency takes over coordination during the ILC on behalf of the EU. That is very significant given the salience that EU positions have on ILC and its non-European delegates. Meanwhile the intra institutional struggle on who represents the Union has not gone away and the sharing of competences is fraught with difficulties. To illustrate, the Commission has twice (in 1994 and again in 2003) unsuccessfully attempted to formalise the coordination process in the ILO (Saenen and Orbie 2011). Such formalisation would have offered the Commission a degree of intra institutional authority that member states are reluctant to concede.

This type of coordination has had a visible effect on the ILO approach. In its 2008 Declaration on 'Fair Globalisation', a document 'marking the most important renewal of the organization since the Declaration of Philadelphia' (ILO 2008: 4), the ILO stressed that employment promotion goes through the upgrading 
of individuals' skills and competences to meet contemporary challenges (ILO 2008: 9). EU-ILO cooperation was on evidence in the run-up to the Declaration, as strong internal EU coordination led to agreement with the ILO on the main policy priorities through tripartite meetings on this subject in 2007 and 2008 (European Commission 2008: 9; Interviews 1, 2 and 5).

A 2009 ILO policy document prepared by the Employment and Social Policy Committee 'for discussion and guidance' reinforces the impression that flexicurity is a policy issue in which the EU has taken the lead and the ILO has sought to deepen the concept and expand its reach beyond Europe. It conceives flexicurity as a clear alternative to the flexibility debate of the 1980s and 1990s and distinguishes its policy content from the overtly liberal reform drive of the Washington Consensus period (ILO 2009a).

Even more interestingly, the same document relies on the organisation's regional expertise to draw a summary of flexicurity practices focusing on Asia, Africa and Latin America. It identifies certain flexicurity policies, though these lack the 'institutional depth' found in Europe. The document supports the need to deepen the flexicurity debate in the developing world and recommends that policy-makers work towards that goal (ILO 2009a: 13). Doing so could help redirect the debate away from pure flexibility approaches and assist these countries in setting up institutional frameworks to combine flexibility with security. This, however, should take place in ways that consider the 'institutional and fiscal constraints' within which policy-makers operate, an echo of similar EU warnings. The concluding section leaves no doubt as to the work that the ILO envisages for itself. Flexicurity is relevant for all countries, not only European ones (ILO 2009a: 14; Interview 6) and the ILO could do more to broaden its work on flexicurity by identifying linkages to other flexibility types, such as wage and functional flexibility (ILO 2009a: 15).

While the overall ILO approach is in harmony with the EU understanding of flexicurity its tone is less enthusiastic. On the issue of social cohesion and change in the labour market the ILO strikes a cautious tone and perceives an imbalance:

Discussions on employment policies, social security and labour market regulation have shown more concern for competitiveness and the stimulation of change rather than for social cohesion or the reconciliation of conflicting interests. (ILO 2006: 17)

One of flexicurity's most important aspects is the notion of flexibility and changing jobs over one's work cycle. The ILO highlights data showing how a stable employment relationship enhances productivity, employee motivation and investment in human capital. It is worth noting that the ILO's desire to stress the more progressive elements of the flexicurity package is in harmony with ETUC's point of view on the subject.

Issues surrounding the definition of the concept also relate to a reluctance to conceive flexicurity as part of an overall macroeconomic policy strategy that relates not only to labour laws and flexibility but also the financing of social security, demand led economic stimuli and so on (Interview 7). The ILO has become 
somewhat sceptical regarding the usefulness of the term as of late, despite strongly backing it at first, not least through its flexicurity project in Eastern Europe. Now it prefers referring to 'labour market security' (Auer 2007), that is, policy measures to protect employees from adverse effects of unemployment whilst in transition from one job to another. As trade union support for flexicurity policies is declining and the term comes under fire from a large part of the research community its future remains vague (Auer 2010).

When it comes to the coordinative part of its discourse on flexicurity, it is clear that the ILO has been very much influenced by the EU approach and has fully endorsed the concept's validity as an acceptable form of reform, though not without some reservations. The EU influence on the ILO's coordinative discourse stems in part from the latter's effective intra-coordination between various institutions and prior to major ILO decision-making forums.

\section{Communicative discourse}

The ILO began researching the concept in 2000 , though it did not define it very concisely. A large project aiming to enhance flexicurity in Central and Eastern Europe was launched in 2002 (Cazes 2008: 3). The 2005 European Regional Meeting 'encouraged the Organization to pursue tripartite consultations on flexibility and security and facilitate the exchange of good practices' (Cazes 2008: 3). Flexicurity could go a long way in supporting the ILO's Decent Work strategy (ILO 1999) since it entails all four elements (employment, social protection, social dialogue and workers' rights) central to it (Auer and Gazier 2008: 7).

A key ILO document in this respect is 'Changing Patterns in the World of Work', a report coming out of the ILO' 95th session in 2006. Secretary General Juan Somavia argued that 'balancing the need for flexibility and security in a period of opportunity and uncertainty requires a strong rights-based approach to the governance of labour markets that fosters social dialogue' (ILO 2006: viii). The Secretary General saw flexicurity from the prism of 'good globalisation', that is, part of a global standards setting agenda that sets labour rights at the heart of the process of adaptation. This is further evident when the report identified four major trends that affected contemporary labour markets. While technological innovation and the intensification of competition and trade liberalisation were clearly identified as drivers of change, the report added the 'shift in political thinking towards greater reliance on markets and a reduced role for the state' (ILO 2006: 3). Clearly, then, globalisation is conditioned, inter alia, by a new type of political thinking regarding the right balance between the state and the market.

An important aspect of flexicurity is the issue of unemployment benefits and striking the right incentives to take up employment. The 2006 report rejected a targeted approach to benefits and backed an active labour market policy combined with tighter qualifications for benefit recipients. On flexicurity per se the report underlined the 'lively character' of the debate in Europe. Without addressing the debate directly it adopted a sympathetic tone by stressing how this 'model for employment adaptation' consisted of consultations with unions and public authorities and was backed up by the social security system (ILO 2006: 55). Clearly, the rhetoric on flexicurity adopted by the EU is fully compatible with 
the ILO's raison d'être concerning the need for social dialogue consultation and inclusion in the policy making process. Moreover, for both organisations flexicurity is a means to an end. For the EU it is a fitting way to fulfil the requirements of the Lisbon Agenda (and, following Lisbon's failure, the Europe2020 targets on labour market policy) and for the ILO it is perfectly compatible with the Decent Work strategy.

The ILO released a fact sheet on flexicurity on the occasion of its eighth European regional meeting in 2009. This document directly contrasted flexicurity with flexibility. Given ILO's mission and work on flexicurity as well as its previous policy pronouncements on this subject it is clear that the organisation criticises flexibility whilst endorsing the innovative and 'new' character of flexicurity. A positive and negative undertone to the two processes can be discerned:

Policymakers all over Europe are facing a crucial challenge of regulating a rapidly evolving labour market in the context of a globalized economy. Will they listen to calls made for greater flexibility or can they place their trust in a 'flexicurity' model: new ways of balancing flexibility and security in relation to employment, income and social protection? (ILO 2009c: 1)

Finally, the document is significant because, in confirmation of data presented above, it assigned a primary role to the EU in dealing with the concept whilst seeing it as 'exportable' elsewhere too:

In the EU-15 increased emphasis has been placed on seeking a better combination of flexibility and security ... ILO analysis ... has also confirmed the relevance of the flexicurity approach for the new EU member states and non-EU countries, where high levels of flexibility are currently combined with low employment and income security. (ILO 2009c: 1)

The attempt by the International Labour Office to disseminate the flexicurity concept beyond Europe has taken a concrete form. The Employment Policy Department released a study ${ }^{4}$ in 2007 devoted to flexicurity in developing countries (De Goobi 2007). It stressed the need to take the flexicurity debate further and embed it in the debate taking place in the developing world. Flexicurity is preferred to flexibility; this is particularly obvious considering the frequent references to the high degree of flexibility already evident in the developing world, as well as the low income and employment (in)security that informality and weak state institutions offer.

The report confirmed the relevance of flexicurity for the non-western world and mentioned concrete policy initiatives. These included India's 2005 Rural Employment Guarantee Act, which promoted employment coupled with social security for landless families (De Goobi 2007: 43-4). The Indian Act followed the principles of the ILO's 'New Consensus' in 2001, which stressed the need to offer social security coverage to the informally employed and create conditions for decent work through income security. The initiative by Uruguay to set up an 
ear-marked tax supporting social security schemes targeting home workers and informal casual workers was part of the same paradigm.

As in its coordinative discourse then, the ILO follows the EU lead when communicating flexicurity. It expresses some reservations on its implementation on the field, possibly reflecting its different mandate. Yet there is little doubt that it sees flexicurity as an alternative to the flexibility dominated policies and policy prescriptions of the 1980s and 1990s. Moreover, the discourse the ILO embraces makes clear that this is a concept relevant beyond Europe and this provides the background for its decision to engage in flexicurity oriented work in other parts of the world. Finally, with reference to globalisation, the ILO's discourse also accepts the inevitability of globalisation when assessed on the basis of changes in technology and labour markets. Nevertheless, it mentions the ideological elements behind this process and ascribes ideational as well as material characteristics to globalisation.

\section{Conclusion}

The EU and the ILO develop their coordinative and communicative discourses quite differently. As far as the coordinative discourse is concerned, the EU counts on external consultation, that is, consulting relevant NGOs, associations, employer and firm federations and trade unions. It does so as a result of its 'stakeholding' understanding on public policy and its desire to incorporate views outside the institutions so as to legitimise its role and function. The main form of coordination at EU level resides with the efforts undertaken primarily by the Commission, often in cooperation with the European Council. As it has been shown, the Commission after the Delors era and the European Council identify globalisation as a real policy constraint in the labour market calling for change, hence their embrace of flexicurity. On the other hand the ILO's coordinative discourse is qualitatively different from the European Union's yet also strongly related to it. It is different because of the organisation's reliance on the International Labour Office to produce informed views on the current state of the labour market that will feed into decision making. Moreover, the ILO does not engage in the type of stakeholders-driven consultation the EU engages in. Yet our data shows how the ILO's coordinative discourse is influenced by EU activism on the field, not least through the latter's coordination efforts at ILCs and the acceptance of EU leadership on the issue.

Whereas the EU uses globalisation as a policy constraint when coordinating its discourse on flexicurity, communicative discourse reveals that the Commission makes use of globalisation as a rhetorical device to strengthen its own role within the Union's institutional matrix and division of power. Concretely, the Commission seeks to expand the implementation and use of flexicurity so as to strengthen its own role in the EU, given the key role it plays in coordinating the Union's and member state policies in that field through initiatives such as the OMC and policy instruments such as the EES. This logic is not transferable to the ILO. What we observe here instead is a more guarded approach to the ideational content of globalisation when applied to labour market policy and an attempt to communicate parts of the flexicurity agenda more amenable to 
workers' interests. This is combined with an acceptance of EU leadership in setting the parameters of the flexicurity agenda and a desire to communicate the concept beyond Europe. Finally, the EU through both the Commission and member states is actively contributing to the message on flexicurity the ILO seeks to communicate.

Focusing on discourse has exposed interesting differences between the institutional reality of the cooperation between the EU and the ILO and the more manipulative use of globalisation at the discursive level. It can be argued that globalisation and Europeanisation are interwoven at an institutional level but at a discursive level globalisation is usually presented as the engine of change, even if this is not always true. Distinguishing between coordinative and communicative discourse has sometimes proven to be a theoretical exercise rather than an empirical reality because neither organisation consciously differentiates its coordinative from its communicative discourse. An additional difficulty is that by analysing discourse at a more complex multilevel environment, different layers of coordinative and communicative discourse are revealed. For example before the 'entry' of flexicurity at the EU level diverse coordinative and communicative discourses on flexicurity were formed at member state level (Antoniades 2008). This prior discursive layer is important because, as it is shown in the article, it has affected the EU coordinative and communicative discourse on flexicurity. Even more significantly, the existence of different layers of discourse and the different styles of leadership exercised by the Commission show that discourse is dynamic and not static.

However, the distinction between coordinative and communicative discourse offers important insights in the way globalisation and Europeanisation shape the concept of flexicurity at different times. The EU's coordinative discourse on flexicurity is structured around the alleged constraints that globalisation is placing on its room for policy manoeuvre. The ILO's coordinative discourse is structured around the EU's solution to the problem, and flexicurity is seen as a 'best practice' transferable from the European to the international level.

The communicative discourse of both the EU and the ILO instrumentally uses globalisation in a variety of ways to present and legitimise flexicurity to the general public. We can go a step further and argue, in agreement with Jacoby and Meunier (2010) that the EU has been a central actor in shaping the concept of flexicurity and via the ILO the global environment of labour market policy. In contrast to what a large part of the literature suggests, the EU is not acting as an antidote to globalisation's alleged imperatives on labour market reform. Rather, it seeks to export its own policy preferences and sees itself constrained by globalisation in what it can do. The implications of this approach are far-reaching. They suggest that, should the parameters of the EU discourse concerning labour market reform remain unchanged, the Union is likely to continue trying to exit the economic crisis by adopting yet more 'flexibility' policies at the expense of employee security. If globalisation calls for more competitiveness via more flexible labour markets, a paradigm well established in the EU today at member state and Commission level, then the lure of flexicurity will increasingly concentrate on its employer-friendly solutions and less on what it offers to workers. One could in fact argue that such a trend is already evident, and the 
ETUC position on the subject presented above suggests as much. Through the Commission's coordinative and especially communicative discourse flexicurity serves as a model for the rest of the international community. Even if the ILO has not adopted flexicurity uncritically, it considers it to be the framework within which its labour policy should stand and interprets it as a refreshing change from the old, flexibility-obsessed approach.

Looking at the international rather than the domestic level to understand the relationship of globalisation and Europeanisation has proven fruitful. Using the EU and the ILO as institutional manifestations of Europeanisation and globalisation, respectively, reveals the institutional interdependence of the two phenomena. More comparisons of the EU with other international organisations in setting discourses, norms, rules and thus state policies would be of great interest.

\section{Notes}

Many thanks to our interviewees at the ILO and the EU for their time and useful insights. Comments and suggestions by the participants of the Political Economy Research Workshop, University of Sheffield, December 2011, as well as Colin Hay, Simon Bulmer, Vivien Schmidt, and three anonymous referees who greatly enhanced the quality of the article. All remaining errors are entirely our own responsibility.

1. We thank an anonymous referee for alerting us to this dimension of the debate.

2. The similarity in outlook between the views expressed in this consultation paper and the policy stance adopted by the European Commission and BusinessEurope on the issue of change and modernisation is evident. Note, however, that 'Europe's Social Reality' is not an official Commission document and does not necessarily express Commission views.

3. Unless otherwise stated this section draws on Boockman 2003.

4. This is an ILO publication. Note, however, that the document includes a disclaimer stating that the author expresses personal views and recommendations.

\section{References}

Antoniades, A. (2008), 'Social Europe and/or Global Europe? Globalisation and Flexicurity as Debates on the Future of Europe', Cambridge Review of International Affairs, 21 (3), pp. 327-46.

Auer, P. (2007), 'In Search of Optimal Labour Market Institutions', in H. Joergensen and P.K. Madsen (eds), Flexicurity and Beyond: Finding a New Agenda for the European Social Model (Copenhagen: DJOF Publishing), pp. 67-98.

Auer, P. (2010), 'What's in a Name? The Rise (and Fall?) of Flexicurity', Journal of Industrial Relations, 52 (3), pp. 371-86.

Auer, P. and Gazier, B. (2008), 'Flexicurity as a Policy Agenda', CESifo DICE Report 4.

Blyth, M. (2002), Great Transformations: Economic Ideas and Institutional Change in the Twentieth Century (Cambridge: Cambridge University Press).

Boockman, B. (2003), Decision-Making on ILO Conventions and Recommendations: Legal Framework and Applications, IINS Research Paper No. 2 (Mannheim: Centre for European Economic Research).

Cazes, S. (2008), 'Flexicurity in Europe': A Short Note on Challenges and Opportunities', paper presented for the European Social Model in the Context of Globalisation, High Level Group: 1-3 July 2008.

Cerny, P. (1996), 'Globalization and Other Stories: The Search for a New Paradigm for International Relations', International Journal, 51 (4), pp. 617-37.

Council of the European Union (2007), 'Towards Common Principles of Flexicurity - Draft Council Conclusions', 15497/07, Brussels, 23 November.

Council Presidency (2006), 'Bartenstein: Forward Together with the Social Partners for a Social Europe'. Available from: www.eu2006.at/en/News/Press_Releases/January/2001bartenstein.html [accessed 3 March 2012]. 
De Goobi, M.-S. (2007), Flexibility and Security in Labour Markets of Developing Countries: In Search of Decent Work for All, Employment Policy Department 2007/6 (Geneva): ILO).

Della Sala, V. (2004), 'The Italian Model of Capitalism: On the Road between Globalization and Europeanization?' Journal of European Public Policy, 11 (6), pp. 1041-57.

Eichhorst, W. et al. (2010), External Dimension of EU Social Policy. IP/A/EMPL/ST/2009-02, PE 440.287 (Brussels: European Parliament, Committee on Employment and Social Affairs).

ETUC (2007), 'The Flexicurity Debate and the Challenges for the Trade Union Movement'. Available from: http://www.etuc.org/IMG/pdf/Depliant_Flexicurity_EN.pdf [accessed 5 June 2011].

Euractiv (2007), 'Trade Unions Sceptical of EU Flexicurity Plans'. Available from: http://www.euractiv.com/en/ socialeurope/trade-unions-sceptical-eu-flexicurity-plans/article-165010 [accessed 26 June 2011].

European Commission (2004), Memorandum of Understanding (Brussels and Geneva: EC and ILO).

European Commission (2006), 'Modernizing Labour Law to Meet the Challenges of the 21st Century', COM (2006)708, final.

European Commission (2007a), 'Commission Communication on Flexicurity', MEMO/07/256, Brussels.

European Commission (2007b), 'Towards Common Principles of Flexicurity', COM (2007)359, final.

European Commission (2008), 'Report on the EU Contribution to the Promotion of Decent Work in the World', SEC (2008)412, final. Available from: http://ec.europa.eu/europeaid/what/social-protection/documents/ decent-job-eu.pdf.

European Commission (2010), 'Lisbon Strategy Evaluation Document', SEC (2010)114, final.

European Commission (2011), Europe2020: An Agenda for New Skills and Jobs (Luxembourg: Publications Office of the European Union).

European Council (2008), 'Implementation of the Common Principles of Flexicurity', 17047/1/08 REV 1 (en).

European Expert Group (2007), Flexicurity Pathways: Turning Hurdles into Stepping Stones (Brussels: June).

Giddens, A. (1998), The Third Way: The Renewal of Social Democracy (Cambridge: Polity).

Graziano, P. (2003), 'Europeanization or Globalization?', Global Social Policy, 3 (2), pp. 173-94.

Hall, P. (1993), 'Policy Paradigms, Social Learning, and the State: The Case of Economic Policymaking in Britain', Comparative Politics, 25 (3), pp. 275-96.

Hay, C. and Rosamond, B. (2002), 'Globalization, European Integration and the Discursive Construction of Economic Imperatives', Journal of European Public Policy, 9 (2), pp. 147-67.

Hay, C. and Smith, N. (2010), 'How Policy-Makers (Really) Understand Globalization: The Internal Architecture of Anglophone Globalization Discourse in Europe', Public Administration, 88 (4), pp. 903-27.

Hay, C., Watson, M. and Rosamond, B. (1999), 'Globalisation, European Integration and the Persistence of European Social Models', Working Paper 3/99, POLSIS, University of Birmingham, UK.

Hughes, S. and Haworth, N. (2011), The International Labour Organisation: Coming In from the Cold (London: Routledge).

ILO (1999) Decent Work: Report by the Director-General, International Labour Conference, 87th session (Geneva: ILO).

ILO (2006), Changing Patterns in the World of Work: Report of the Director General, International Labour Conference, 95th session (Geneva: ILO).

ILO (2008), ILO Declaration on Social Justice for a Fair Globalization (Geneva: ILO).

ILO (2009a), Combining Flexibility and Security for Decent Work, Committee on Employment and Social Policy, GB.306/ESP/3/1 (Geneva: ILO).

ILO (2009b), 'Protecting People, Promoting Jobs: A Survey of Country Employment and Social Protection Policy Responses to the Global Economic Crisis', ILO report to the G20 Leaders' Summit, Pittsburgh, 24-25 September.

ILO (2009c), 'Facts on Flexicurity: 8th European Regional Meeting'. Available from: http://www.ilo.org/ wcmsp5/groups/public/-dgreports/-dcomm/documents/publication/wcms_101645.pdf [accessed 4 November 2010].

Jacobsson, K. (2004), 'A European Politics for Employability: The Political Discourse on Employability of the EU and the OECD', in C. Garsten and K. Jacobsson (eds), Learning to be Employable: New Agendas on Work, Responsibility and Learning in a Globalising World (Basingstoke: Palgrave), pp. 42-62.

Jacoby, W. and Meunier, S. (2010), 'Europe and Globalization', in M. Egan, N. Nugent and W. Paterson (eds), Research Agendas in European Union Studies: Stalking the Elephant (Basingstoke: Palgrave), pp. 353-74.

Jepsen, M. and Pasqual, A.S. (2005), ‘The European Social Model: An Exercise in Deconstruction', Journal of European Social Policy, 15 (3), pp. 231-45. 


\section{Dimitris Tsarouhas \& Stella Ladi}

Johnson, A. (2003), 'Social Policy at the Global Level: EU Member States at the ILO', paper presented to the 8th Conference of the European Union Studies Association, Nashville, TN, March, 27-29.

Jordana, J., Levi-Faur, D. and Puig, I. (2006), 'The Limits of Europeanization: Regulatory Reforms in the Spanish and Portuguese Telecommunications and Electricity Sectors', Governance, 19 (3), pp. 437-64.

Jørgensen, H. (2011), Danish "Flexicurity” in Crisis - Or Just Stress-tested By the Crisis? (Berlin: Friedrich Ebert Foundation).

Keune, M. and Jepsen, M. (2007), 'Not Balanced and Hardly New: The European Commission's Quest for Flexicurity', in H. Jørgensen and P.K. Madsen (eds), Flexicurity and Beyond: Finding a New Agenda for the European Social Model (Copenhagen: DJØF Publishing), pp. 189-214.

Kissack, R. (2009), 'Writing a New Normative Standard? EU Member States and ILO Conventions', in J. Orbie and L. Tortell (eds), The EU and the Social Dimension of Globalization (London: Routledge), pp. 98-112.

Ladi, S. (2006), Globalization and Europeanization: Analysing Change. Working Paper 4 (Barcelona: Institut Barcelona d'Estudis Internacionals).

Levi-Faur, D. (2004), 'On the 'Net Impact' of Europeanization: The EU's Telecoms and Electricity Regimes Between the Global and the National', Comparative Political Studies, 37 (1), pp. 3-29.

Liddle, R. and Lerais, F. (2007), Europe's Social Reality (Brussels: Bureau of European Policy Advisers).

Mailand, M. (2010), 'The Common European Flexicurity Principles: How a Fragile Consensus was Reached', European Journal of Industrial Relations, 16 (3), pp. 241-57.

Nedergaard, P. (2008), 'Coordination Process in International Organizations', European Integration Online Papers, 12(3).

Peters, G. (2011), 'Ideas as the Foundation of Institutions: Discursive and Constructivist Institutionalism', Institutional Theory in Political Science (New York: Continuum), pp. 147-64.

Radaelli, C. (2003), 'The Europeanization of Public Policy', in K. Featherstone and C. Radaelli (eds), The Politics of Europeanization (Oxford: Oxford University Press), pp. 27-56.

Rosamond, B. (2003), 'Babylon and On? Globalization and International Political Economy', Review of International Political Economy, 10 (4), pp. 661-71.

Rosamond, B. (2008), Globalization and the European Union (Basingstoke and New York: Palgrave).

Saenen, B. and Orbie, J. (2011), 'Challenges to Coherence: Exploring the European Union's Role in the International Labour Organization', in J. Lieb, N. von Ondarza and D. Schwarzer (eds), The EU in International Fora: Lessons for the Union's External Representation (Nomos: Baden-Baden), pp. 159-74.

Scharpf, F.W. (2002), 'The European Social Model: Coping with the Challenges of Diversity', Journal of Common Market Studies, 40 (4), pp. 645-70.

Schmidt, V. (2002), 'Does Discourse Matter in the Politics of Welfare State Adjustment?', Comparative Political Studies, 35 (2), pp. 168-93.

Schmidt, V. (2008), 'Discursive Institutionalism: The Explanatory Power of Ideas and Discourse', Annual Review of Political Science, 11, pp. 303-26.

Schmidt, V. and Radaelli, C. (2004), 'Policy Change and Discourse in Europe: Conceptual and Methodological Issues', West European Politics, 27 (2), pp. 183-210.

Tangian, A. (2007), 'European Flexicurity: Concepts, Methodology and Policies', Transfer, 13 (4), pp. 551-73.

Verdier, D. and Breen, R. (2001), 'Europeanization and Globalization: Politics Against Markets in the European Union', Comparative Political Studies, 34 (3), pp. 227-62.

Viebrok, E. and Clasen, J. (2009), 'Flexicurity and Welfare Reform: A Review', Socio-Economic Review, 7, pp. 305-31.

Wallace, H. (2000), 'Europeanization and Globalization: Complementary or Contradictory Trends?' New Political Economy, 5 (3), pp. 369-82.

Wilthagen, T. and Tros, F. (2004), 'The Concept of "Flexicurity": A New Approach to Regulating Employment and Labour Markets', Transfer, 10 (2), pp. 166-86. 